\title{
Long Term Migratory Dynamics and Context of a Territory: French Guiana
}

\author{
Paul Roselé Chim \\ HDR University of Paris 1-Panthéon Sorbonne \\ Beta Emadd Bio Minéa UR 7485 \\ University of French Guiana
}

\author{
Moustapha Aladji \\ Beta Emadd Bio Minéa UR 7485 \\ University of French Guiana \\ Mamadou Diop \\ University of Dakar Senegal
}

France, like other former European immigration countries, such as Belgium, the Netherlands, Germany and the United Kingdom, has recorded significant waves of foreign workers, sometimes accompanied by members of their family. In the 1950's and 1960's until mid-seventies, the first oil shock put a stop to active policies of recruiting foreign workers, but until today, immigration has not ceased fueled mainly by family reunification and the influx of refugees.

From this context, it is important to ask the following question: how have migratory policies evolved in France since 1901 till date? How is this development beneficial to the regional economic integration of Guyane-one of the French territories bordered by Brazil and Suriname? The primary objective of this article is to compare migratory policies from 1901 to present day and to examine their impact on the integration and economic development of Guiana as well as their causes.

Keywords: migration, politics, immigration, international standards

\section{INTRODUCTION}

French Guiana is a territory that has been under constant migratory pressure throughout its history. Its path of development is marked by waves of immigration explained by the need of the population to meet the demand for labor in the sectors under tension: agriculture, fishing, gold mining, space industry, rum industry, housing and construction etc.

Periods of civil wars in neighboring countries, such as Suriname or the rise of poverty in Guyana and northeastern Brazil, has influenced the population growth of French Guiana. The latter keeps the mark. It 
must be observed that the economic and social conditions of the immigrant population in these territories are reflected in development imbalances.

French immigration laws do not always consider the territorial specificity of a country bordered by Brazil and Suriname. The dynamics of migration is in context of underdevelopment of an attractive country. Immigration is economic. This study seeks to study the dynamics of migration in the territory over a long period. Three approaches will be taken:

- A literature review to understand different aspects of the labor market between nationals and non-nationals.

- An examination of the notion of "migration" through various migratory policies developed in France.

- Data analysis and empirical estimation

The objective is to try to draw lessons through the comparison of migration policies in France from 1901 to 2018 and to understand their impact on the integration and economic development of French Guiana.

We conclude towards a dual selection of migration by questioning the dynamics of the balance between growth, development and the attractiveness of the territory.

\section{LITERATURE REVIEW}

There have been numerous scientific researches on migration. Therefore, there is a great number of literatures on this study. This extensive literature shows some evolution in the economic conclusions about the influence of immigration on the labor market. As a result, we will see below, the economic and legal aspects of migration: an approach based on the general equilibrium theory and international legal norms on migration.

The rights of the individual and therefore the rights of immigrants are often considered to be in opposition to the sovereignty of the state, but we forget that, in many cases, the very exercise of State sovereignty makes it possible to protect these rights or to sustain the institution of these rights. In fact, States are bound to respect human rights, either because they have ratified the conventions that protect those rights (in which case the signatory States have expressly consented to any resulting limitations on their sovereignty), or by the norms of customary international law which are considered certain only if they are widely accepted practice of States and if they generally consider them as legally binding obligations.

It must be added that, according to prevailing doctrine in international law, States are bound only by the norms to which they did not object at the time of their adoption. Momentarily, human rights norms are not the work of a deus ex machina: they reflect the practice and will of the States

\section{Economic Aspect: Approach to Immigration by the Theory of General Equilibrium}

Theorists tell us that the most coherent and rigorous approach to the problem of immigration would be to develop a growth model based on the theory of general equilibrium and characterized by a system of simultaneous equations, to account for the interactions between immigration and the various processes of economic growth.

Most theorists of the 18th and 19th centuries believed that migration represented a process of international economic equilibrium, since the decline in labor supply, implied in the countries of emigration, led to an increase the remuneration of this factor, from which Adam Smith's statement in 1776: "All help to those unfortunates who [...] devote themselves to their brother by moving away from them".

However, some theorists do not share this view. This is the case of Malthus who remains consistent with his "law of population" (1798), when he insists on the inadequacy of emigration as a solution to the overpopulation of a country.

Less than a century later, when (John Stuart Mill 1848) declared that migration is a means of combating the trend of diminishing returns to the land, he also considered it a remedy for low wage rates and the decline in profit rates ("the more we send [capital and men] abroad, [...], the more we can keep at home"). 
In fact, if emigration allowed the wage rate of the population residing in the country to exceed the subsistence level, the resulting natural increase of the population would neutralize the beneficial effects of this emigration. Contrary to Marx, who supports this idea, emphasizing that the agricultural revolution and the natural increase of the remaining population can neutralize the positive consequences of emigration, as it was the case for "Ireland, where production relative to overpopulation has more than compensated for absolute depopulation ".

We note here that, the classic authors were mainly concerned with the impact of migration on the economy of the country of emigration, considering that the advantage for the country of immigration is often a country of allies (through trade) or a country of colonization.

Nowadays, researchers are much more interested in the consequences of migration on the countries of immigration. Some studies on the impact of international migration on countries of emigration are relatively rare except for special aspects such as "capital transfers from immigrants to their country of origin, etc.".

According to the different points of view of these theoreticians, if one wants to evaluate the role of the "equilibrium machine" of migration, it is necessary to analyse simultaneously the devices facilitating migration and its impact on the country of emigration and on the country of immigration. According to the "neoclassical" theory, migration lowers the level of wages in the immigration countries, because the arrival of an immigrant workforce implies an increase in labour supply, that is, a shift from the labour supply curve to the labour demand curve to a lower point

In the country of emigration, on the other hand, the fall in labour supply resulting from emigration leads to an increase in the wage rate. In sum, wage level increases in the poorest country (emigration country) and decline in the rich country (or at least wage growth will be slower).

Several theories and models of international (and regional) development have been inspired by this "neo-classical" conception and continue to be based on it. Whereas, despite two centuries of international migration, sometimes massive and the almost continuous rural exodus, it is important to note that real wage differentials between rich and poor countries (or rich and poor regions) have remained, in most cases, if they have not increased.

According to the neoclassical approach, migration is perceived as a process of relocating production capacity, and its impact on the level of wages manifesting itself only through a shift in labour supply. A migrant is, however, both a producer and a consumer, and he is (generally) a producer.

\section{Economic Effects of Immigration}

The work of Stephen Castles and (Godula Kosack, 1972) considers immigration as arising from a structural necessity in response to the needs of capital and management. This builder text on the economic contribution of immigrants sets out a series of hypotheses that will shape research later. It is a very important current in Europe, which is still valid today for several forms of immigration, particularly immigration of the least qualified, irregular immigration and temporary migration in certain sectors such as construction and catering. But the essential contribution of Castles and Kosack has been to insist on the existence of a hierarchy in the structure of jobs, with immigrants often at the bottom of the socio-economic ladder, thus reinforcing the division of the working class.

In line with the work of Castles and Kosack, Marxist-inspired studies have tended to emphasize the negative effects of immigration. This negative perception will be reopened in the research on migration and development, this part will be discussed in the next article. More recently, studies on more global economic effects of immigration (at the macro level) indicates less contradictory and uncertain results (Héran 2002). The most important limitation of this work is methodological. Most researchers agree that existing methods of analysis do not allow definitive conclusions to be drawn.

This also explains the great variance in the results, which vary between positive, negative, or undefined effects. In all cases, the measured effects remain very low, or even insignificant. A first reason for this methodological limitation is the fact that the number of parameters that should be considered in the models is considerable. A second reason is more fundamental: the evaluative studies consider the short term whereas the full benefits are only visible in the medium and long term (Goldin et al., 2011).

Unfortunately, such long-term analyzes are rare. 
If we look at the American study by (Carter and Sutch, 1999), over a long period covering the nineteenth and part of the twentieth century, the beneficial aspects of migration emerge clearly. Indeed, immigration can have significant impacts on the entire economic structure, including activity rates, the level of skills of the population, the quantity and quality of capital and the organization of production (Carter and Sutch, 1999).

Another more recent review of the debate on the effects of immigration in developed countries concludes that, overall, the effects are positive, both from the point of view of growth and from the point of view of innovation and contributions (Goldin et al., 2011, Chapter 6). The methods of calculating economic integration as well as the interpretation of the new results are constantly modified.

\section{International Legal Standards on Immigration and Border Control}

Numerous bilateral, regional or multilateral agreements and treaties aim at regulating migration, particularly in the humanitarian field. Some of these rules are properly adapted and others are incomplete, but there are no rules of law or guidelines for cooperation between States. There is no such thing as a global institution to effectively and efficiently engage in such population movements, justice problem and the respect required by the interests of the countries of origin, transit and destination.

And, although politicians are gradually becoming aware that national decisions will not be enough to solve the problem facing Guiana, and that the subject of immigration is increasingly raised at the national and regional levels, so far, there have been no concrete and collective initiatives to open dialogue with neighboring countries such as Brazil and Suriname on the full range of migration issues in the region, apart from cooperation in terms of economic exchange.

A few years ago, the Swiss Federal Office for Refugees launched the Berne Initiative ${ }^{1}$, which aims to improve the management of migration and immigration regionally, and where possible, globally through cooperation between States. This initiative would therefore lead to a dialogue between the countries of departure and the countries of arrival, first in the regional framework, then at the global level, which could lead to the creation of an intergovernmental framework in conformity with certain principles of a general nature and endowed with the necessary means to help the communities and certain services of the State like the prefecture, when they are confronted with problems of migration, legal or illegal immigration.

International migration is an indisputable element of the social and economic life of our time, and every territory in the world is confronted with this reality. They cannot help but to seek means of building a real cooperation between themselves in this matter. Our world is a world of inflow and outflow of states and individuals. It is also a world of borders that people cross for a variety of reasons: to work, to visit their families, to escape violence and natural disasters, to study, to heal or to return to their country. And virtually all states are trying to control their borders, people entering and leaving their country.

It is sometimes said that States have every right to regulate these passages across their borders and that this right, if not exercised, would weaken their sovereignty and ability to define themselves as a nation. On the other hand, it is often said that migrants as people have basic rights that migration regulation cannot restrict. This debate, however, leaves out some crucial aspects of international legality as it exists today, and does not do enough justice to cooperative efforts to regulate migration in the common interest of states and migrants. There is indeed a detailed, if not complete, set of legal rules, multilateral conventions and bilateral agreements that limit and regulate the power of States in this area.

The arguments in favor of unlimited power of national and regional authorities must therefore be rejected, especially since these norms are not imposed from above, as if they were the product of a world authority having conceived a universal plan of the movement of people that states should respect. Here, International legal standards in this area would therefore be considered from a point of view other than that of the simplistic debate between the authority of states and the rights of migrants. Instead, we would attempt to identify the legal norms that may constitute the future framework of a cooperative effort that responds to the interests of the States, their mutual relations and their citizens, in a way consistent with the United Nations Charter, which is intended to "achieve international cooperation by solving international economic, social, cultural or humanitarian problems by developing and promoting respect for human rights and fundamental freedoms for all without distinction of race, sex, language or religion ". 
As we have already mentioned, international law contains precise standards on certain aspects of migration, many of which are included in conventions concluded between States (such as the principle of non-refoulment, which prohibits return of persons to states where they may be persecuted); others which, elaborated over the years, are part of customary international law (for example, the obligation of States to admit the entry into their territory those of their citizens who wish to return to it) to which is added a number of international, regional or bilateral agreements that impose reciprocal obligations on signatory states in areas such as human trafficking, international trade, free movement of migrants within the regional framework or the rights of migrant workers.

On other issues, it is true, international standards are less clear or less comprehensive. Let's give some examples ${ }^{2}$. Although the right to family reunion is recognized in widely ratified human rights instruments, it seems more difficult, except in the case of refugees, to speak of a clear right to migration when it aims at reuniting a family (in other words, the right of people to join their family members in another state) ${ }^{3}$. While the obligation to rescue people at sea is clearly asserted, there is no precise rule on where these people may land ${ }^{4}$.

States can impose certain limits based on citizenship, but the standard that would limit the possibilities of discriminatory decision in this area is not firmly established. Even in other fields, there is no legal standard formulated with precision, or even of which one can hope for its appearance. Neither the question of dual nationality nor the modalities of integration of immigrants, for example, are the subject of international standards of a general nature.

In each of these areas, co-operative efforts are required between States. To sum up: the firmly established norms reflect the existence of a general harmony between nations, new or insufficiently precise standards call for a common work of productive interpretation, and areas of lawlessness are obviously subject to examination in the context of international politics.

Migration is often conceived as a triangular relationship between an individual, the state from which he comes and the receiving state, but a full description must, inter alia, take into account the role of transit countries, migrants in the state of departure and the state of arrival, employment opportunities in the state of departure, transporters, smugglers, traffickers, and sources of persecution whose action causes individuals to flee.

\section{ON THE CONCEPT OF MIGRATION POLICIES IN FRANCE}

\section{The Concept: Migration Policies}

The International Organization for Migration defines the concept of migration policy as "the collective principles by which a government is shaped in its management of migration". It considers this management as a "term uniting the numerous governmental functions induced by a national system of methodical and humane management of cross-border migration, the administration of the entry and presence of foreigners on the national territory and the protection of refugees and all kinds of foreigners in need of protection. This term refers to a planned approach to developing a political, legislative and administrative response to the challenges posed by migration. This rather generic definition indicates that migration policy is the management tool for foreigners (and not immigrants). The term migration policy therefore refers to all the actions of the public authorities of a country in terms of the management of individuals who are not nationals of that country and who are either present on their territory or who wish to return.

Therefore, this general term includes both legislative provisions and administrative practice relating to the movement of foreigners on the national territory, as well as provisions specific to the living conditions of temporary or permanent ${ }^{5}$ foreign residents. In this article, we would examine migration policy as the sum of migration legislation and its application. Nevertheless, as defined, migration policy faces the difficulty of its measurement, particularly in terms of interpretation and application by individuals. 


\section{France's Migration Policies Over a Very Long Period: Analysis of Objectives Between 1901 and Present Day}

Towards the end of the 19th century, France became a country of immigration. From 1850 to 1900 , while the rest of Europe almost triples its population, that of France no longer increased: this was the primary reason for migratory flow at the beginning of the century, lack of manpower everywhere, at the countryside as well as in cities; neighboring countries were the main suppliers of labor (mainly Italy, Belgium, Spain and Switzerland, Poland for the recruitment of minors in the North) ${ }^{6}$.

Until 1917 a simple declaration of their residence to the mayor was enough for foreigners to settle in France and practice a profession. Meanwhile during the First World War, North African, Indochinese and Chinese workers were recruited through the Ministry of Armament.

In the aftermath of the First World War, the double phenomenon of mass immigration and nation building that had developed in the second half of the 19th century disintegrated, France became a country of immigration despite this. It ended up welcoming and settling a population whose stay was considered short-lived. Since the beginning of the twentieth century, international conventions signed with Italy (19041906), Belgium (1906), Poland and Italy (1919), Czechoslovakia (1920) provided recruitment of workforce and the Ministry of War even organized a recourse to colonial labor.

Immigration from North Africa, unwanted by some, was growing, thanks to the removal of travel permits for Muslims in Algeria in 1913. A mixed system, the External Service of Foreign Labour (SMOE), developed a labour policy between 1919 and 1937: "Born in urgency and renewed by prosperity, this service made immigrants work by means of bilateral labour agreements, approved employment contracts and regularized the situation of tens of thousands of immigrants without work contract?

The "General Society of Immigration" created in 1919, an emanation of the employers who took charge of recruitment, was, however, overwhelmed by illegal immigration (only $35 \%$ of entrants were introduced by him between 1924 and 1930). During the economic crisis of the 1930s, immigration continued while unemployment increased, the rules of the game were so fragile and disputed, and France became the country with the highest rate of foreigners in the world, ahead of the United States, against a backdrop of lack of men and low birth rate: 3 million foreigners, or $7 \%$ of the total population.

With these clarifications, we can distinguish three major waves of immigration to France since the nineteenth century. They each correspond to a period of economic expansion. The first wave dates from the late nineteenth century, during the "boom" of the Second Empire. The second wave took place during the $1920 \mathrm{~s}^{8}$. The third wave corresponds to the Thirty Glorious. These three waves of economic expansion and influx of migrants were later followed by brutal breaks in economic crises.

In 1924, there was an unprecedented growth in immigration, more varied: Polish, Czechoslovak, with the appearance of a political immigration (Armenians, Spaniards, Germans, Italians, Russians). From 1927 until 1940, there was the organization of recruitments through the general society of immigration, constituted by specialized employers' organizations.

A year later, a new law gave priority to the work of French workers in industries ${ }^{9}$ by introducing quotas of foreign workers in companies. In 1934, aid for the repatriation of voluntary workers was decided. Highly represented in parliament, towards the end of this period, lawyers passed a law prohibiting naturalized Frenchmen from being admitted to the bar for a period of 10 years.

Under the Vichy government in 1940, a foreign policy was developed just after a law on the status of Jews put all Jews on a societal ban. The law of October 4, 1940, on foreign nationals of Jewish race, made it possible to restrain them in special camps by the decision of the prefect of their department of residence. On September 27, 1940 a new law concerning other non-Jewish foreigners was born and settled the question of the number of foreigners in the national economy. The alien was subject to close supervision, he was no longer entitled to free movement within the territory and he no longer benefitted from the labor legislation.

Nowadays, regarding the European policy on immigration and integration, France has defined its strategy around three main axes of action: the control of migratory flows, the integration of regular immigrants and the guarantee of exercise of the right of asylum for persons seeking the protection of France according to the ratification of the Geneva Convention in 1954. 
These axes form part of a migration management policy whose objective is to adapt regular immigration to the economic and social realities of France. This requires not only to adjust the issuing of residence permits but also to fight, with the support of European partners, against illegal immigration.

As such, the focus is on improving controls with, for example, the introduction of biometrics in visas, or the fight against misuse of procedures. Priority is obviously given to the fight against sectors that exploit the precariousness of people wishing to settle in the territory and who participate in human trafficking. The policy of integration of regular immigrants is based primarily on language learning, knowledge of the values and customs of the French society and access to employment. It also aims at the integration of specific audiences such as refugees, immigrant women or elderly immigrants. The integration process begins with the signing of the Welcome and Integration Contract (CAI). Immigrants have the obligation to attend various training sessions and information sessions such as civic training day to introduce them to the institutions, organization and values of the French Republic or, depending on their level knowledge of French, language training.

France has a tradition of welcoming asylum seekers. The right to asylum is both a constitutional requirement, an international commitment under the Geneva Convention and a Community obligation. France has been able to consolidate an asylum system which guarantees the impartial examination of the application by an independent institution, the French Office for the Protection of Refugees and Stateless Persons (OFPRA) which is under the control of an administrative court, the National Court of Asylum Law (CNDA). It provides asylum seekers with the right to stay, except for the limited exceptions enumerated, as well as the right to housing and social care.

\section{The Establishment of a Migration Control Policy in France}

On May 19, 1974 Valéry Giscard d'Estaing was elected President of the Republic. His immigration policy was defined by stopping all new immigration, by a rigorous control of entries and stays (a whole arsenal of circulars and decrees was signed during this period or modified), by encouraging voluntary returns of immigrants to their country of origin and, finally, by a program of integration of those who are established in France

On 5 July 1974, upon the proposal of André Postel-Vinay, appointed the head of State Secretariat for Immigrant Workers, created on 7 June 1974, the French Government decided to suspend the immigration of workers and families, except for the European Community. The immigration of workers thus remained suspended until 1977. The immigration of families was reauthorized since 1975.

In the 1980s, the promulgation of Law 80-9 (known as the Bonnet Law) on the prevention of illegal immigration and amending the Ordinance of 2 November 1945 on the conditions of entry and residence in France of foreigners: made conditions of entry into the territory more strict; it made irregular entry or residence a ground of expulsion in the same way as the threat to public order; it therefore allowed "illegal immigrants" or those whose residence permit has not been renewed to be removed from the territory; finally, it provided for the deportation of the expelled alien to the border and his detention in a penitentiary for a period of up to seven days if he is not able to leave the territory immediately.

On June 14, 1980, Mr. Lionel Stoléru, then Secretary of State to the Minister of Labor and Participation (manual and immigrant workers) stated that "it is no longer a question of welcoming a single foreigner to France". The following day, these remarks were condemned by the unions CGT and CFDT and by the Federation of associations of solidarity with immigrant workers (FASTI) ${ }^{10}$.

On May 10, 1981, upon the arrival of Mr. François Mitterrand to the Presidency of the Republic, the data changed. On May 27, 1981, instructions from Gaston Defferre, then Minister of Interior, reached the prefects concerning the expulsion of foreigners: suspension of all expulsions; granting a temporary residence permit to foreigners benefiting from this suspension; prohibition to expel foreigners born in France or entered France before the age of ten.

\section{The Rights of Foreigners: An Evolution of the Status of Immigrants in France Between 1981-2014}

From 1981 to 2000, many reforms, such as the policy statement of Mr. Pierre Mauroy, Prime Minister at the time, were born. Gaston Defferre's circular as Minister of Interior relaxed the living conditions of 
foreigners residing in France regarding evictions for residence and asylum. In September 1981, an examination by Council of Ministers of two draft laws on the conditions of entry and residence of immigrants and the employment of illegal aliens took place, resulting in the adoption of a draft law, guaranteeing the freedom of association of foreigners.

The law of 27 October 1981 repealed the provisions of the Bonnet law and introduced into the ordinance a series of new guarantees for foreigners ${ }^{11}$. On July 17, 1984 Law 84-622 on the single title of stay and work was voted unanimously. It recognized the lasting nature of the settlement in France of the immigrant population and dissociated the right to stay from the occupation of a job.

On May 9, 1985, François Mitterrand, President of the Republic, declared at the inauguration of the High Council of Population and Family, the "need to fight against the drop-out and to approach with" openness and generosity "the problem of immigration" ${ }^{12}$.

In May 1995, ten years later, Jean Jacques Chirac was elected President of the Republic. In June 1996, in Paris and several cities, demonstrations for the "regularization of undocumented migrants" took place. The occupation of the Saint-Hyppolite church in Paris by foreign parents of French children, or the occupation of the Saint-Bernard de la Chapelle church, in the 18th arrondissement of Paris by about 200 undocumented Africans are examples of these demonstrations.

On June 25 of that same year, hundreds of immigrants "without papers" occupied the town hall of the 18th district of Paris, to claim regularization. On the same day, Mr. Claude Frickart, Auxiliary Bishop of Paris, denounced "the injustice and immorality of a number of immigration laws", and wanted the administration to regularize the undocumented, "in the name of the fundamental right to live as a family "

Three years later, in Luxembourg, at a meeting of the European Ministers of Justice and Interior, which took place on 4 October 1999, devoted in particular to the preparation of the forthcoming Tampere summit (Finland), France, Germany and the United Kingdom presented a common contribution on immigration policy: rejection of "zero immigration" and "total freedom of installation"; invitation to define a development policy with the countries of origin of migrants.

On 27 June 2000 a report of the European Commission against Racism and Intolerance, an organ of the Council of Europe, invited France to revise its "egalitarian republican model" because of discriminations particularly encountered by young people from immigration (access to employment, housing and public places, police conduct)

The data presented, demonstrated a statutory and administrative evolution of immigrants and foreigners in France over the last five years. In the period between 2010 and 2015, we find that the share of foreigners or immigrants who had received a first residence permit for family reunion was much larger than those who had applied for a residence permit for reason of continuous studies.

This is explained by the migration policy of the 1950s until the mid-1970s, when France welcomed foreigners with their family members to overcome the problem of labor. The industrial revolution reached France late: it was under the Second Empire between 1851 and 1870 that it really started. The slowing of French population growth since the eighteenth century, and this new need for labor encouraged immigration of workers from neighboring countries.

This was the beginning of the first wave of immigration in France. According to the French regions, the first immigrants were Belgians and "Piedmontais" (a name usually given to people coming from the States which will later be Italy) (14) as well as the Swiss. Italian immigration, a country with high population growth, then took over from Belgians and Swiss, the status of Nice and Savoy (annexed in 1860 by Napoleon III) favoring cross-border movements. Spaniards and Germans also emigrated to big French cities and participated in the economic development and demographic filling of France.

From 1851, the State included in the census data on nationality (with many approximations because this notion was poorly defined and mostly understood in a variable way by the population) and place of birth, thus providing a basis for estimating the number and proportion of foreigners in France. The administration then identified 380,000 foreigners, including 63,000 Italians. The Italians were more than 100,000 at the end of the Second Empire; 163,000 in 1876;240,000 in 1881 and 330,000 at the turn of the 20 th century. 


\section{THE MIGRATION POLICY: ANALYSES OF THE TERRITORY OF FRENCH GUIANA AND EMPIRICAL ESTIMATION}

Guiana, which is in South America, covers an area of $86,504 \mathrm{~km}^{2}$ and is the largest of the French regions. It has $300 \mathrm{~km}$ of coastline, $520 \mathrm{~km}$ of borders with Suriname and $700 \mathrm{~km}$ with Brazil ${ }^{14}$. Its population density is 2.9 per inhabitant per square kilometer. With a population of over 254,000 in 2017, the average annual population growth is $2.2 \%$ per year over the last five years. However, since 2011, the high population growth has been due to the natural balance only, whereas before, population growth was reinforced by the surplus of net migration.

In Guiana, the diversity of the population is because of migratory waves of successive arrivals. It was composed mainly of Amerindians, Creoles, Blacks, Asians and Metropolitans in the early $1960 \mathrm{~s}^{15}$. It then diversified with the arrival of native immigrants from Brazil, Haiti, Guyana, Suriname or Saint Lucia. Until the 1980s, large waves of immigration to Guyana reflected political instability in the surrounding countries: political unrest in Haiti, civil war in Suriname, social and economic problems in Guyana.

Today, Guyane remains an island of wealth in the heart of South America and many immigrants come to settle there for economic or family reasons. Moreover, it should certainly be emphasized that permeability of the borders makes Guyane a land of migration: two frontier rivers, forest to the south and the sea to the north. The number of immigrants in the Guyanese population was stable in 1990. Thereafter, between 1990 and 1999 a decrease took place. In 2009, immigrants made up 29.7\% of Guyane's population. This was the highest regional reception rate compared to Île-de-France $(17.6 \%)$ and Alsace $(10.3 \%)$. If the origin of the immigrant population has changed over time, its profile has also changed: there are now more women than men.

The history of the population of Guyane showed great waves of migration. Of native origin, the term "Guiana" comes from the Guano dialect, the Indian population of the Orinoco Delta in Venezuela. Guai would mean "name ${ }^{16}$," "denomination," and Yana is a negation. Guyana is an Italian term for the Guiana massif. "Guyana" means "without name". Guiana would be the land that one dares to call "the sacred land", "the house of the supreme being" according to the natives.

Guyane is considered a "hot spot" in terms of biodiversity but it is also marked by its multicultural aspect. Indeed, if we investigate the origin of the population, research shows that it comes from all over the world. This "Melting Pot ${ }^{17 "}$ was not only formed by the history of Guyana, but also by various geopolitical events around the world.

In 1952, Indonesians arrived in Guyane to promote agriculture. The first Hmong arrived in Guyane in 1974 and a second wave of migration followed in 1977. They came to settle in Cacao to flee the Indochina war, with the help of France

In 1986, the massacre of civilians and the ensuing civil war in Suriname caused very strong immigration of Surinamese to Guyane: 6,340 people settled in Saint-Laurent du Maroni and Mana.

In 1958, the dictatorship of Duvalier in Haiti caused the departure of many waves of Haitian migrations. It will follow those of 1967, 1973, 1979, 1981, 1984, 1990, and 1992. The policy of family reunion led by O.M.I. at the beginning of the 90's allowed a rebirth of the Haitian immigration between 1990 and 1999.

In addition, Guyane was subject to spontaneous migration of thousands of gold prospectors due to the large undeveloped deposits in French Guiana and the course of the yellow metal for more than 15 years (between 20,000 and 40,000 euros per kilogram).

\section{A Land of Insufficient Means for Receiving Immigrants}

The conduct of migration flows in Guyane raises many questions, be they economic, legal or social. The Maroni and Oyapock rivers are certainly borders but they are also important vectors of economic, social, cultural and matrimonial exchanges. Population movements are extremely difficult to supervise. The issue is also strategic and geopolitical ${ }^{18}$.

The status and living conditions of foreigners cannot therefore be considered as peripheral issues; they are truly at the heart of all territorial public policies: schools, vocational training, housing, health, employment, social cohesion, etc. 
After several attempts for centuries to populate this territory considered hostile, a change in discourse has been perceptible since the late 1970s, both on the side of local elites and the state. "The immigration so much demanded by the Guianese, after having responded to the planned call [ particularly the construction of the Space Centre in Kourou, ed], jostled all the forecasts and overflowed the psychological capacities of reception of the Guyanese. The immigrant population of all origins and all nationalities, in the early 1980s, was likely to be larger than those "born in Guyana".

"The flow of immigrants altered the ethnic and racial composition of the population and called into question the superiority of the Guianese Creole who, until the beginning of the 1960s, occupied exclusively the political and cultural space reserved for the inhabitants of the country. (...) In this new context, Guyane closed itself to the idea of any new immigration. Immigration was now perceived as a danger for the emergence of the "Guyanese people ${ }^{19 "}$

In a more global concern to control its migration policy, the French State in its own way emphasized the risk of a large influx of foreigners. Some question the capacity of a country where the labour market fails to absorb the already active workforce. Is it therefore necessary, as suggested by the High Council for Integration, to regulate arrivals according to the reception possibilities of the regions? ${ }^{20}$

Our approach here is not to deal with these issues that are essentially political debate. However, our study clearly underlines the lack of means devolved for the reception and accompaniment of foreigners in French Guiana. Already identified in mainland France ${ }^{21}$, these gaps are even more striking in this territory because of the growing volume of applications. Hence many difficulties of integration for these oftenmarginalized populations, and a risk of destabilization of the Guyanese society.

With 5176 first asylum applications in 2017, Guyane is one of the French departments where the asylum application is the most important (first among the DOM). At the same time, it is one of the territories where the recognition of protection (refugee status or subsidiary protection) is the lowest. Only $2.3 \%$ of OFPRA decisions recognize protection against $7.5 \%$ for all DOMs and $9.4 \%$ in metropolitan France ${ }^{22}$. After recourse to the CNDA, figures are $9 \%$ for Guyana against $25 \%$ in mainland France.

Regarding applications for residence permits, the prefecture of Guyane counted 4,000 first applications in 2012 and 8,500 in 2013. In 2012, 3,023 applications (or 76\%) were accepted and 3,148 in 2013 (37\%). The difference is largely due to the entry into force of the circular Valls ${ }^{24}$ in November 2012: the latter relaxes the criteria for admission to stay for people present for more than 5 years in the territory without residence permit. The requests then increased significantly, but many of them did not meet all the criteria required by the circular ${ }^{24}$.

Thus, many foreigners in an irregular situation have been refused a request for regularization. This rise in flows was partly anticipated by the administration at the Prefecture of Cayenne (with the establishment of a specific reception), but not at the sub-prefecture of Saint-Laurent du Maroni, which must nevertheless face an increasing number of cases. The obstacles faced by users are multiplied in Guyane: difficulties in collecting civil status documents that must be apostilled or legalized; excessive cost of the residence permit for applicants whose income is often very low (or non-existent); need to provide a passport proving the applicant's identity even though other documents may, according to the law, serve as proof.

The steps to file an application for a residence permit are therefore slowed down. Another major difficulty: the absence of issuing a receipt when filing the application for resident permit, even though the code of entry and stay of foreigners and the right to asylum provides for its issuance automatically. Without a receipt, the applicant for a residence permit is found to be in an irregular situation.

Hence, frequent breaches of access to the law. The problem is the same for renewals of temporary permits $(16,508$ were issued in 2013 , or $83 \%$ of all securities issued). The procedure provides that individuals must apply for renewal of their residence permits two months before the expiry of the previous one so that there is no break between the two resident permits. Even if most people respect this deadline, the prefecture of Guyane is not able to handle all the requests in the given times. As a result, people regularly find themselves staying illegally between these periods. Because of this administrative precariousness, social workers and associations often find that the people concerned are penalized when they want to have access to social rights. Finally, it becomes more complicated to justify a continuous regular stay and to obtain resident card. It is the whole integration process that is questioned. 


\section{Immigration and the Demographic Growth of the Territory}

(Piantoni 2011) portrays immigration as it is today, by its burden in population growth and the socioeconomic strategies it deploys, emblematic of the relationship between globalized processes and local strategies $^{25}$. In addition, "population growth [...] is combined with an economy that is highly dependent on metropolitan transfers and a binding legislative framework that generates social inequalities ${ }^{26 "}$

What drives us here to evoke the failure of the initial settlement strategy, the policy of integration in Guyane creates a dependence vis-à-vis the metropolis limiting its development. It also highlights the residual nature of immigration, especially compared to other neighboring countries such as Suriname and Brazil. This reflects the importance of choosing the scale of study and its relative weight compared to the rest of the country.

For example, nationalities of origin of immigrants such as Brazilian or Surinamese, who are nevertheless overrepresented in the Guianese population, are displayed in the "other" category in the national statistics, which does not make it possible to differentiate them.

Moreover, the immigration policies planned in the 18th century, with colonial occupation, prison and gold mining, which brought the West Indians, French and Asians, after the departmentalization, was to support an economic development program (the CSG, infrastructures), which set up an opening for immigration from not only South America but also from the Caribbean.

Several years ago, there were other factors that promoted population growth of this territory and the population of Guyane. As you can see in the two graphs below, the contribution of natural and migratory balances to the annual growth rate and population change between 2013 and 2030.

The graph shows us that the increase of the population by 2030 would be essentially driven by natural balance, births would each year be much higher than deaths. Fertility, life expectancy and migration are the three components of population change, but in Guyane, demographic change by 2030 would depend mainly on assumptions about fertility, in line with past trends (figure 2$)^{27}$.

By 2030, Guyane would gain 72,000 inhabitants (Figure 3), if demographic trends at the beginning of the decade in terms of fertility, mortality and migration continue. The population of Guyane would continue to grow strongly each year, rising from 244,119 in 2013 to 316,000 in $2030^{28}$.

After Mayotte, Guyane would remain the most dynamic French region with an average annual population growth of $1.5 \%$ between 2013 and 2030 and nearly $30 \%$ over the entire period. At the same time, the population of hexagonal France would increase by $7 \%$, while Guadeloupe and Martinique would experience a demographic decline (decreases of $8 \%$ and 12\% respectively over the period 2013-2030).

Guyane's population growth would remain strong throughout the 2013-2030 period, with a slight deceleration in the pace of growth. From an annual average of $1.8 \%$ over the $2013-2020$ period, the population growth rate would increase to $1.4 \%$ on average over the $2020-2030$ period.

The three components of the change in the number of inhabitants are fertility, life expectancy and migration. If we change the assumptions of change in the number of births, deaths and migrations, the alternative scenarios produced makes it possible to qualify the projections of the population. Thus, if we apply the scenario called "young population" and so-called "elderly population", Guyanese population would be between 336000 and 295000 inhabitants respectively in 2030. Whatever the scenario, population growth would continue at least until $2030 .^{29}$

\section{Empirical Estimation}

Our approach focuses on analyzing the results of survey data on the economic and social situation of immigrants living in French Guiana. Our objective is to analyze the unaccompanied effects of this population on their integration. Using the observed data from our sample, we will perform a descriptive analysis and a chi-square test to verify the relationship between the different variables that explain the integration or precariousness of this population.

Our analyzes are inspired by the literature relating in particular to the work of researchers such as, Delphine Nakache ${ }^{30}$, Matthieu Boussichas ${ }^{31}$, Frédéric Piantoni ${ }^{32}$ and some international organizations like the International Organization for Migration (IOM), the System of Permanent Observation of Migrations (SOPEMI ), the Organization of Economic Cooperation and Development (OECD), the French Office of 
Immigration and Integration (OFII), Documentation Française (DF), the National Institute of Demographic Studies (INED), National Institute of Statistics and Economic Studies (INSEE) will be used as data, the extract from the census of the population (RP 2017) and the data of the survey that we carried out with the immigrant population.

\section{Survey Plan}

This sampling plan presents the advantages and limits of the use of a sample in the survey that we conducted among the different immigrant families living in the territory of Guyane. The survey was conducted to answer the following question: "how the inefficiency of support systems to the integration of migrants can contribute to their precariousness".

The survey took place in three communities (Cayenne, St Georges and St Laurent du Maroni) It was carried out at four levels, specific data collected are: duration in the territory, access to rights, administrative situation, nationality, activity and income to correctly decipher the sampling methodology used. The Chisquare test results will answer the question.

\section{Target Population and Sample Size}

The target population was immigrants to carefully determine the size of our sample which has a great importance on the accuracy of the estimates made. For economic reasons, it was necessary to use the smallest possible sample while obtaining enough level of confidence and a margin of error.

In this survey, the size of our sample depended on the confidence level of the study and the sampling rate $\mathrm{p}$;

With $\mathrm{P}=\mathrm{n} / \mathrm{N}$

Risk threshold or (the margin of error) is $5 \%$

Confidence level 1- $\alpha=95 \%$ of the confidence level.

The accuracy of the survey is noted $4 \%$.

\section{Application}

In this survey, we did a two-stage cluster survey because of time and cost constraints. We could not do the study across the whole territory, so we chose these three communes: St Georges, St Laurent du Maroni and Cayenne.

The sample size was 601 migrant households, with survey accuracy of $10 \%$ with a $95 \%$ confidence level and a 5\% confidence threshold.

$$
\begin{gathered}
\mathrm{P}=10 \% .(\mathrm{t} \alpha) 2=1.96 \\
\text { With } \mathrm{p}=10 \%
\end{gathered}
$$

\section{Decision Analysis of Observed Variables and Chi-Square Test}

The purpose of this decision analysis is to make a comparison of the variables using chi-square test $(\chi 2)$ to verify the hypotheses according to which, within the immigrant population, if there is dependency or independence to variables. This de 2 test provides a method for determining the nature of a distribution that can be continuous or discrete.

\section{Chi-Square Test Procedures}

If the two variables are independent, this expression follows a Chi-square distribution with a number of degrees of freedom equal to: $(p-1)(q-1)$. In a table, we read $\chi 2$ value having a probability $\alpha$ of being exceeded $\alpha, \mathrm{k}$ for a distribution of $\chi^{2}$ with $\mathrm{k}=(\mathrm{p}-1)(\mathrm{q}-1)$ degrees of freedom. The margin of error of our sample is $5 \%$. 
TABLE 1

TABLE OF RESULTS OF CHI-SQUARE TEST (TABLE)

\begin{tabular}{|c|c|}
\hline Hypotheses & $\begin{array}{l}\text { H0: } \chi 2=0 \text { independence, then reject hypothesis } \\
\text { H1. } \\
\text { H1: } \chi 2 \neq 0 \text { dependence, so we reject the } \\
\text { hypothesis H0. }\end{array}$ \\
\hline $\begin{array}{l}\text { Variable: expenditure -duration: } \chi 2=23.35> \\
21.02 \text { We accept hypothesis } H 1 \text { at } 95 \%\end{array}$ & $\begin{array}{l}\text { Analysis of the variables present indicates that there } \\
\text { is a dependency. The expense variable influences } \\
\text { duration. }(\chi 2=23.35 \mathrm{dd} 1=12, \mathrm{p}=21.02) \text {. It can } \\
\text { therefore be concluded that the less recent this } \\
\text { population is, the more it spends on consumption } \\
\text { and rent. }\end{array}$ \\
\hline $\begin{array}{l}\text { Variable: expenditure -salary: } \chi 2=56>21.02 \\
\text { we accept } \mathrm{H1} \text { at } 95 \%\end{array}$ & $\begin{array}{l}\text { We reject the assumption of independence, in the } \\
\text { case of the result of our test, there is } 95 \% \\
\text { dependence, which explains that the expenditure } \\
\text { made are based on income (salary), plus the } \\
\text { individual has a high salary the less he spends, and } \\
\text { the less his salary is high the more he spends to } \\
\text { consume. } \\
\text { This macroeconomic phenomenon is called the } \\
\text { marginal proportion to consume, it is between } 0 \text { and } \\
1\end{array}$ \\
\hline $\begin{array}{l}\text { Variable: Housing -duration: } \chi 2=42.2>15.50 \\
\text { we accept } H 1 \text { at } 95 \%\end{array}$ & $\begin{array}{l}\text { It is concluded that there is dependence, housing has } \\
\text { an impact on the length of stay of immigrants in the } \\
\text { territory. The longer the person stays in the territory, } \\
\text { the more chance they have that the housing situation } \\
\text { will change. The occupation of illegal land for some } \\
\text { immigrants is also a way for them to have a place to } \\
\text { stay. }\end{array}$ \\
\hline
\end{tabular}

\section{CONCLUDING REMARKS}

Regarding all these contributions, we can argue in this conclusion that migration policies in France in the 1950s and 1960s contributed to the reinforcement of foreign labor force both at national level and in its departments and regions. Guyane benefited from this migration policy of the 1950s following the arrival of Indonesians in 1952 to promote agriculture in relation to the lack of local labor.

Since the years 1604, from the French colonization, immigration participated in population growth of Guyane through two types of immigration: spontaneous immigrations and organized immigrations. This form of migration policy played a vital role in the population and economic growth of Guyane at that time.

Recall that this article aims to make a comparison of migration policies in France from 1901 to present day: its impact on regional economic integration of Guyane. 
France's economic immigration policies are now converging towards a dual selection favoring highly skilled workers while framing precarious entries of individuals whose human capital is considered weaker. They are also marked by the fight against clandestine migration, for which there appears to be a consensus among developed countries as to their interest in minimizing illegal and undeclared work.

During a century and a half of immigration that made France the oldest immigration country in Europe, some key dates served as benchmarks for variations around the right to go out, enter and migrate: 1932, with the quota of immigration of manpower; 1945, with the system of opposability of employment and the ambition of an immigration controlled by the State; 1974, with the cessation of regularizations and the suspension of flows of hired labor; 2000, with the announcement by the United Nations of a vital resumption of migration flows.

The border has been at the heart of this evolution because it is perceived, for historical reasons, as the symbolic place of control, even if the essential is played elsewhere at a distance, upstream (entry visas issued in the countries initially) and collectively (through the Schengen and Dublin system), but also downstream (remote police, readmission agreements).

The problem of economic and regional integration of Guyane through the effects of France's migration policies remains unclear because the territory itself is very late in terms of economic development and lacks basic infrastructure.

Guyanese border control refers to triage (entry is already predetermined by sorting) but also gives rise to infringements (transnational networks for which the border, by its very existence, is a resource, "exceptional" regularization of undocumented migrants, bilateral labor agreements), while referring to the sanctions incurred, highly charged with the symbolism of sovereignty (prohibition of territory, renewal and expulsion). The permeability of the border leaves the door open to economic immigration.

\section{ENDNOTES}

1. https://www.sem.admin.ch/sem/fr/home/aktuell/news/2004/2004-12-09.html

2. See expert study from the article « Inter-state Cooperation on Migration Significant Bilateral and Multilateral Agreement $\gg(\mathrm{OIM})$.

3. The Study does not pretend to be a comprehensive review of national standards, nor a comparative analysis of the types of statutory schemes adopted by States.

4. See United Nations Convention against Transnational Organized Crime, 9 janvier 2001, GAOR 55e session, UN Doc. A/Res/55/25, 40 I.L.M. 335 (2001 not yet in force at the time of this publication). Convention signed by 143 States and ratified by 24 . Will enter into force after its fortieth ratification (see idem, article 38).

5. Thesis: Matthieu Boussichas. Migration policies and development: optimizing the effects of emigration. Savings and finances. University of Auvergne Clermont-Ferrand i, 2009. French (page 34).

6. http://www.vie-publique.fr (the historical facts of immigration)

7. Vincent Viet, Immigrant France. Construction of a policy (1914-1997), Paris, Fayard, 1998, p. 32 and following.

8. At the end of the 1920s, France had the highest immigration rate in the world, ahead of the United States

9. http://www.vie-publique.fr (chronology: history of immigration to date)

10. http://www.vie-publique.fr (1945 - 1974: From 1974: End of 30 glorious, establishment of a policy of control of migratory flows).

11. The law of 27 October 1981 repeals the provisions of the Bonnet Law and introduces into the ordinance a series of new guarantees for foreigners: the expulsion can only be pronounced if the foreigner has been sentenced to a sentence of at least one year in prison; the procedural guarantees surrounding deportation are increased; foreigners in an irregular situation can only be returned to the border after a judgment and no longer by administrative means; minor aliens can no longer be expelled, and those with personal or family ties in France may be expelled only in cases of absolute urgency, when the measure constitutes "a compelling necessity for the safety of the State or for public security ".

12. 13.http://www.vie-publique.fr

13. Graphique annexe 1 
Op. Cit (2006)., "Atlas of the immigrant population in Guyane", 2006 Journal of Applied Business and Economics

15. Harpeau. B, 2013, Overview of the immigrant population, INSEE

16. Temporal, F, Breton, D, Marie, C.V, 2002, Impact of foreign immigration on the demographic dynamics of French Guiana, INED

17. It is a metaphor used to describe a phenomenon of assimilation of immigrant populations of various origins into a homogeneous society.

18. CRPV Guyane. Access to the rights of foreigners in Guyana, P.114

19. Serge Mam-Lam-Fouck, History of contemporary Guiana 1940-1982, Paris, Caribéennes editions, 1992, p.408-409.

20. Haut Conseil à integration, "Does France still know how to integrate immigrants? Review of the integration policy in France for twenty years and perspectives ", 2011, p.8.

21. The state has destroyed some of the tools of its policy: loans, institutions, and more importantly, competent staff and the most active associations", in Thierry Tuot, "The great nation for an inclusive society", Report to the Prime Minister on the Rebuilding of Integration Policies, February 1, 2013, p.9. http://www.ladocumentationfrancaise.fr/var/ storage / public-reports / 134000099 / 0000.pdf

22. Source: Ofpra's 2012 activity report.

23. Circular No. NOR INTK1229185C of November 28, 2012.

http://www.gisti.org/IMG/pdf/circ_norintk1229185c.pdf

24. Crpv French Guiana. Access to the rights of foreigners in Guyana, P.114

25. Ibid Piantoni p. 13

26. Ibid Piantoni, p.19

27. Graphique1 annexe $P, 21$

28. Graphique2 annexe, 21

29. Insee: Projection of the population, particularly vigorous population growth in Guyana by 2030 .

30. Researcher at the University of Montreal, Faculty of Law. First version of an issue on migration issues in the North-South economic agreements, presented at the EMMA-RINOS seminar in Paris on May 26 and 27, 2003.

31. Matthew Boussichas. Migration policies and development: optimizing the effects of emigration. Savings and nuances. University of Auvergne- Clermont-Ferrand i, 2009. English

32. Frédéric Piantoni "The migration issue in French Guiana"

\section{REFERENCES}

Baker, M., \& Benjamin, D. (1994). The Performance of Immigrants in the Canadian Labor Market. Journal of Labor Economies, 12(3), 369- 405

Borjas, G. (1985, October). Assimilation, Changes in Cohort Quality, and the earnings of Immigrants. Journal of Labor Economies, 3(4), 463-489

Callovi, G. (2004). L'européanisation des politiques migratoires de l'Union Européenne.

Campbell et Kandala. (2011). Étude sur le Botswana, cité par la Direction de la prévision et des études économiques, Étude de la migration interne au Sénégal: Détermination et impact sur la pauvreté. Dakar, Senegal.

Daudé, L. (2010). les indicateurs démographiques RUP et les immigrés en Guyane. Mémoire de Master, 2. MFDD, Université de Guyane.

Domingues Dos Santos, M. (2005). Travailleurs maghrébins et portugais en France. Le poids de l'origine, Revue Economique, 56, 447-464.

Friedberg, R.M., \& Hunt, J. (1995). The impact of immigrants on host country wages, employment and growth. Journal of Economic Perspectives, 9, 23-44.

Gourévitch, J.P. (2008). le coût réel de l'immigration en France. Working papers, Paris. France.

Gross, D. (2002). Three million foreigners, three million unemployed? Immigration flows and the labour market in France. Applied Economics, 34, 1969-1983.

Harpeau, B. (2013). Panorama de la population immigrés. INSEE, Paris, France.

Héran, F. (2007). le temps des immigrés. Working Papers, Paris, France. 
Hidair, I. (2008). L'immigration étrangère en Guyane : entre stigmatisation et stratégie de récupération. Revue Asylon(s), 4. Institutionnalisation de la xénophobie en France.

Lautier, B. (1984). l'économie du secteur informelle dans les tiers mondes, Paris la découverte, coll. Repères, publié par D. GADELHA. Processos migratorios de brasileiros para a Guiana Francesa instigam pesquisa.

Mam Lam Fouck. (2015). La société Guyanaise à l'épreuve de migration, 1965-2015. Matoury, Ibis rouge. Guyane.

Paugaum, S. (2011). Rapport de la précarité Territoriale (Séance Plénière 16 mars 2011).

Piantoni, F. (2011). Migrants en Guyane. Actes Sud/ Musée des Cultures Guyanaises, Guyane, p.175.

Roger, F. (2018). Les échanges transfrontaliers à dominante fluviale et la dynamique des systèmes agraires à Albina au Suriname. Working papers BETA EMADD BIO MINEA EA 7485, Université de Guyane, for the Conference on Borders and Cities in the Guyanes.

Rosele Chim, P. (1999). Revue Canadienne d'Etude du Développement: Migration, informalité transfrontalière et paradoxe de l'intégration entre PVD. la région des Caraïbes.

Rosele Chim, P. (2007). Les déséquilibres de développement par la migration et l'informel en Guyane française. Edition Ibis Rouge, Cayenne, Guyane Française.

Roselé Chim, P. (2018). Migrations, pratiques informelles et intégration transfrontalière dans un contexte de globalisation et de déséquilibre de développement: le Mexique et les Etats-Unis. Workings papers, BETA EMADD BIO MINEA EA 7485 Université de Guyane, for the Conference on Borders and Cities in the Guyane.

Rosele Chim, P. (2019, May-June). Haitian migration in south America. Characteristics in the framework of chilean development. Paper for the 61th Congress of AIELF, Santiago, Chile.

Rosele Chim, P. (2019). Migration, croissance et développement dans la trajectoire Amérique Sud : Haïti - Guyane française - Brésil - Chili. Revue RIELF, Poznan, Pologne. 


\section{APPENDIX}

This graph illustrates the evolution of the immigrant and foreign population that settled in France between 1982 and 2014.

\section{FIGURE 1}

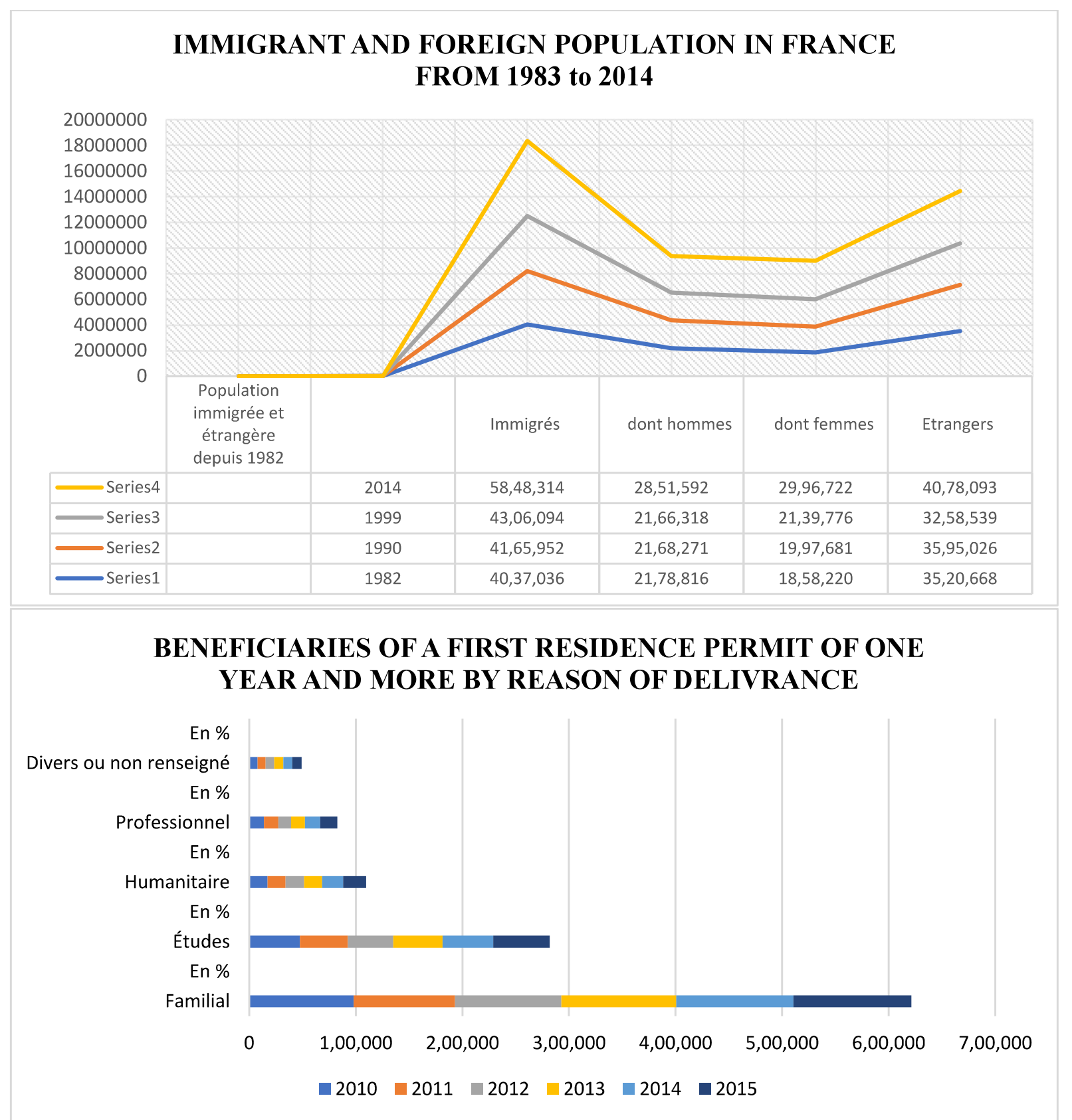

Source: Authors' calculations from AGDREF data; D. Breton, M. Barbieri, H. d'Albis and M. Mazuy: The recent demographic evolution of France: strong contrasts of department, Population-F, 72 (4), 2017, 583-652 
FIGURE 2

\section{CONTRIBUTION COMPARISONS OF NATURAL AND MIGRATORY BALANCES TO THE} AVERAGE ANNUAL GROWTH RATE BETWEEN 2013 AND 2030 OF DOMS

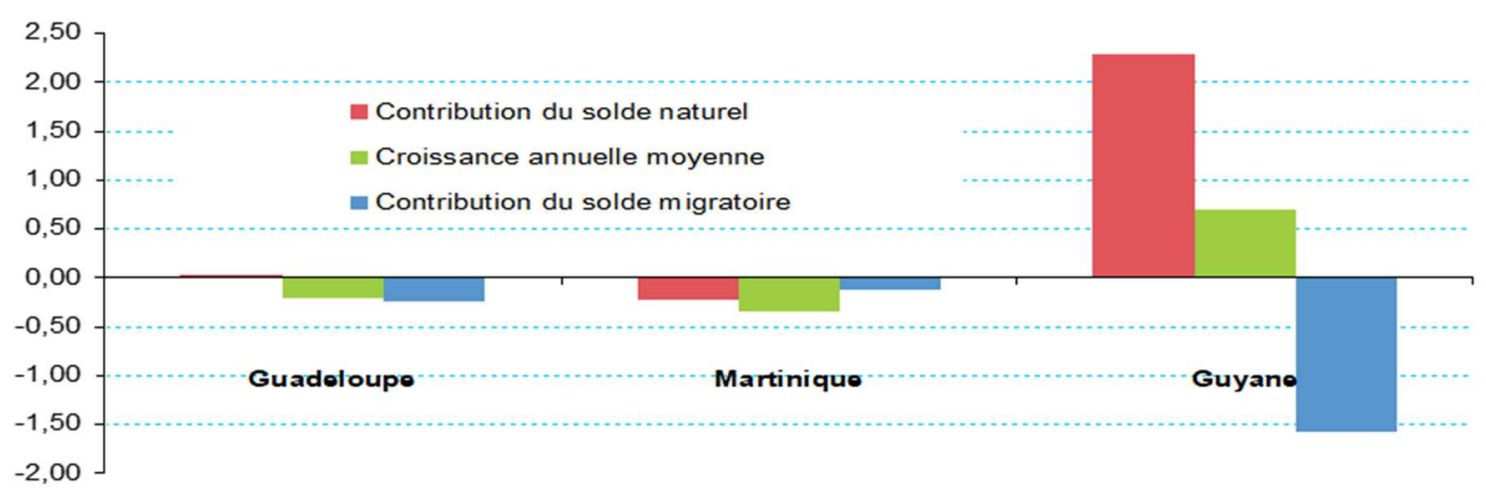

As from the authors with INSEE data

FIGURE 3

EVOLUTION OF THE GUYANESE POPULATION BETWEEN 2013 AND 2030

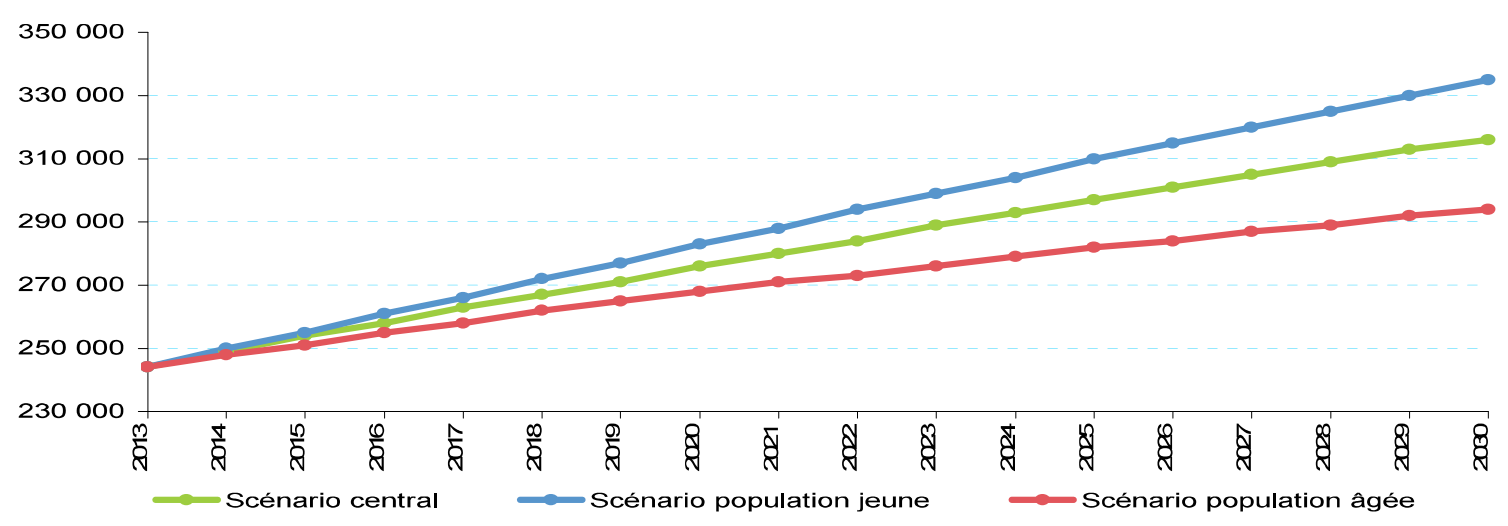

As from the authors with INSEE data 